\title{
A possible 150 million years old cirripede crustacean nauplius and the phenomenon of giant larvae
}

\author{
Christina Nagler ${ }^{1,4}$, Jens T. Høeg ${ }^{2}$, Carolin Haug ${ }^{1,3}$, Joachim T. Haug ${ }^{1,3}$ \\ ${ }^{1}$ Department of Biology, Ludwig-Maximilians-Universität München, Großhaderner Straße 2, 82152 Planegg- \\ Martinsried, Germany \\ ${ }^{2}$ Department of Biology, University of Copenhagen, Universitetsparken 15, 2100 Copenhagen, Denmark \\ ${ }^{3}$ GeoBio-Center, Ludwig-Maximilians-Universität München, Richard-Wagner-Straße 10, 80333 Munich, Germany \\ ${ }^{4}$ E-mail: christina.nagler@palaeo-evo-devo.info
}

Key words: nauplius, metamorphosis, palaeo-evo-devo, Cirripedia, Solnhofen lithographic limestones

\begin{abstract}
The larval phase of metazoans can be interpreted as a discrete post-embryonic period. Larvae have been usually considered to be small, yet some metazoans possess unusually large larvae, or giant larvae. Here, we report a possible case of such a giant larva from the Upper Jurassic Solnhofen Lithographic limestones (150 million years old, southern Germany), most likely representing an immature cirripede crustacean (barnacles and their relatives). The single specimen was documented with up-to-date imaging methods (macro-photography, stereo-photography, fluorescence photography, composite imaging) and compared with modern cirripede larvae. The identification is based on two conspicuous spine-like extensions in the anterior region of the specimen strongly resembling the so-called fronto-lateral horns, structures exclusively known from cirripede nauplius larvae. Notably, at 5 $\mathrm{mm}$ in length the specimen is unusually large for a cirripede nauplius. We therefore consider it to be a giant larva and discuss possible ecological and physiological mechanisms leading to the appearance of giant larvae in other lineages. Further findings of fossil larvae and especially nauplii might give new insights into larval evolution and plankton composition in the past.
\end{abstract}

\section{Contents}

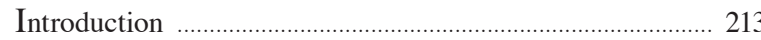

Material and Methods ................................................................. 214

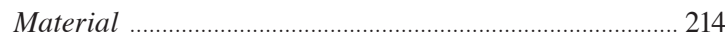

Documentation methods ...................................................... 214

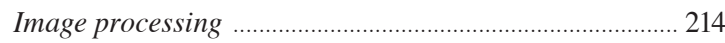

Presentation methods ....................................................... 215

Description of the specimen ………........................................... 215

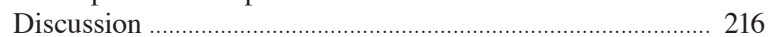

A possible interpretation of the fossil .............................. 216

Difficulties with the interpretation ................................... 218

Other possible interpretations ........................................... 219

Early fossil record of Cirripedia ...................................... 219

Giant larvae in metazoans ............................................... 220

Giant larvae in crustaceans ................................................ 221
The possible function of giant larvae ............................... 222

Interpretation of the present case ....................................... 223

Acknowledgements .................................................................. 223

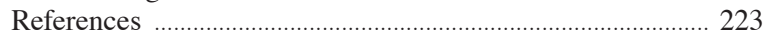

\section{Introduction}

The larval phase of a metazoan organism, an animal, is a discrete post-embryonic period. Different authors apply various criteria what identifies a larva in comparison to a non-larval immature. Among these are, for example, 1) a morphology that is significantly different from that of the adult (Hickmann, 1999), 2) the occupation of a different ecological niche than the adult (Giese and Pearse, 1975; Young, 1999), or 3) the possession of organs that become reduced and are absent in the adult (Strathmann, 1993; Anger, 2001).

In many organisms the larval phase is comparably short, ended by a metamorphosis that produces the juvenile/adult morphology within a short period of time (Passano, 1961). As a consequence of a short larval phase in most organisms the larvae are rather small (Cowen and Sponaugle, 2009).

In classical zoological literature, we often encounter the differentiation between so-called primary and secondary larvae (although the value of this differentiation remains questionable). The first type should represent ancestral larval types, while the second represents derived forms (Werner, 1988). Especially larval forms that are classified as primary are usually microscopic entities, more or less invisible to the naked eye. The trochophora (of annelids and molluscs) and the pluteus (of echinoids) are often given as examples (Young, 2002), although both forms are clearly derived types of 
larvae characterizing specific monophyletic groups (hence, could also be interpreted as secondary larvae). Yet, also many larval forms that clearly fall into the secondary larvae category are often quite small, for example, crustacean nauplii (Martin et al., 2014, fig. 2.3; Haug and Haug, 2015).

Despite the fact that larvae are usually small, in many lineages larvae of astonishing sizes have evolved, i.e., forms that can well be called 'giant larvae'. A rather simple case example is that of flying insects. As flying insects perform a terminal molt and can no longer grow as adults, their larval phase is comparably long and the late stages are quite large, almost as large as the adults (Truman and Riddiford, 2002). Yet, giant larvae are also known in numerous further metazoan groups.

The phenomenon of giant larvae can also be observed in the fossil record. There are cases of exceptional types of fossil preservation that seem only to preserve rather small forms. Most notably, fossils in an Orsten-type preservation include many forms of larval arthropods and larval cycloneuralians, no specimen being larger than $2 \mathrm{~mm}$ (Haug et al., 2014a). Yet, for many other types of preservation especially the large forms appear to have a higher chance to be preserved. For malacostracan crustaceans, we have fossils of especially supersized larvae such as those of achelatan lobsters (Polz, 1971; 1972; 1973; 1995; Haug et al., 2011a; Haug and Haug, 2016), polychelidan lobsters (Haug et al., 2015a; Eiler and Haug, 2016) or mantis shrimps (Haug et al., 2008, 2015b), some of them in thousands of specimens (Polz, 1987; 1996), while smaller-sized larvae like those of crabs are very rare (Haug et al., 2015c). It seems therefore common that giant larvae occur as fossils.

With this contribution we aim at briefly reviewing the known occurrences of giant larvae. Due to the still very incomplete knowledge of Mesozoic plankton (Haug and Haug 2017), the description of a possible further case of a 150-million-year old crustacean larva that was found in the famous lithographic limestones of southern Germany add important details. Additionally, this fossil larva is of unusually large size.

\section{Material and Methods}

\section{Material}

We investigated a single slab from lithographic limestones of Southern Germany (Solnhofen area, Upper Jurassic, Tithonian, southern Germany) found in the hobby quarry near Eichstätt with a single small fossil specimen. The fossil was formerly part of the private collection of Michael Fecke, Langenberg, now transferred to the State Museum of Natural History Stuttgart (SMNS 70409).

For comparison three modern larvae were documented: a thoracican lepadomorph nauplius of the group Lepadidae from the Museum National d'Histoire Naturelle, Paris (MNHN IU-2014-5478), a thoracican balanomorph nauplius (teaching collection LMU Munich), and a rhizocephalan nauplius, Peltogaster paguri, from the private collection of Jens T. Høeg in the Zoological Museum Copenhagen.

\section{Documentation methods}

The fossil specimen was documented with macro-photography, stereo-photography and fluorescence microphotography to extract as much information as possible from it. The lepadomorph nauplius was documented with macro-photography. The balanomorph nauplius was documented with fluorescence micro-photography. The rhizocephalan nauplius was documented with scanning electron microscopy.

Macro-photography and stereo-photography combined with composite imaging were performed (following e.g. Haug et al., 2012; 2013a), both under cross-polarized light. We used a Canon EOS Rebel T3i camera with Canon MP-E (65 mm) macro lens. Illumination was provided by the Canon Macro Twin Lite MT-24EX flash from two opposing sides. Fluorescence microscopy of the fossil was performed on an inverse fluorescence microscope BZ-9000 (BIOREVO, Keyence) with about40 times magnification recording autofluorescence under blue light (GFP, $488 \mathrm{~nm}$; for details on autofluorescence imaging, see Haug et al., 2011b). Fluorescence microscopy on the balanomorph nauplius was performed on a Zeiss AxioScope 2 with about 200 times magnification recording autofluorescence under UV light (DAPI, $358 \mathrm{~nm}$ ). For macro-photography and micro-photography stacks of images (of different focal planes) were recorded to overcome limited depth of field. Adjacent stacks were recorded to overcome limitations in field of view. Scanning electron microscopy of the rhizocephalan nauplius was performed on a JEOL 6335-F scanning electron microscope at the Zoological Museum in Copenhagen.

\section{Image processing}

Stacks of images were fused to sharp images using the freeware CombineZP. Resulting sharp images were 


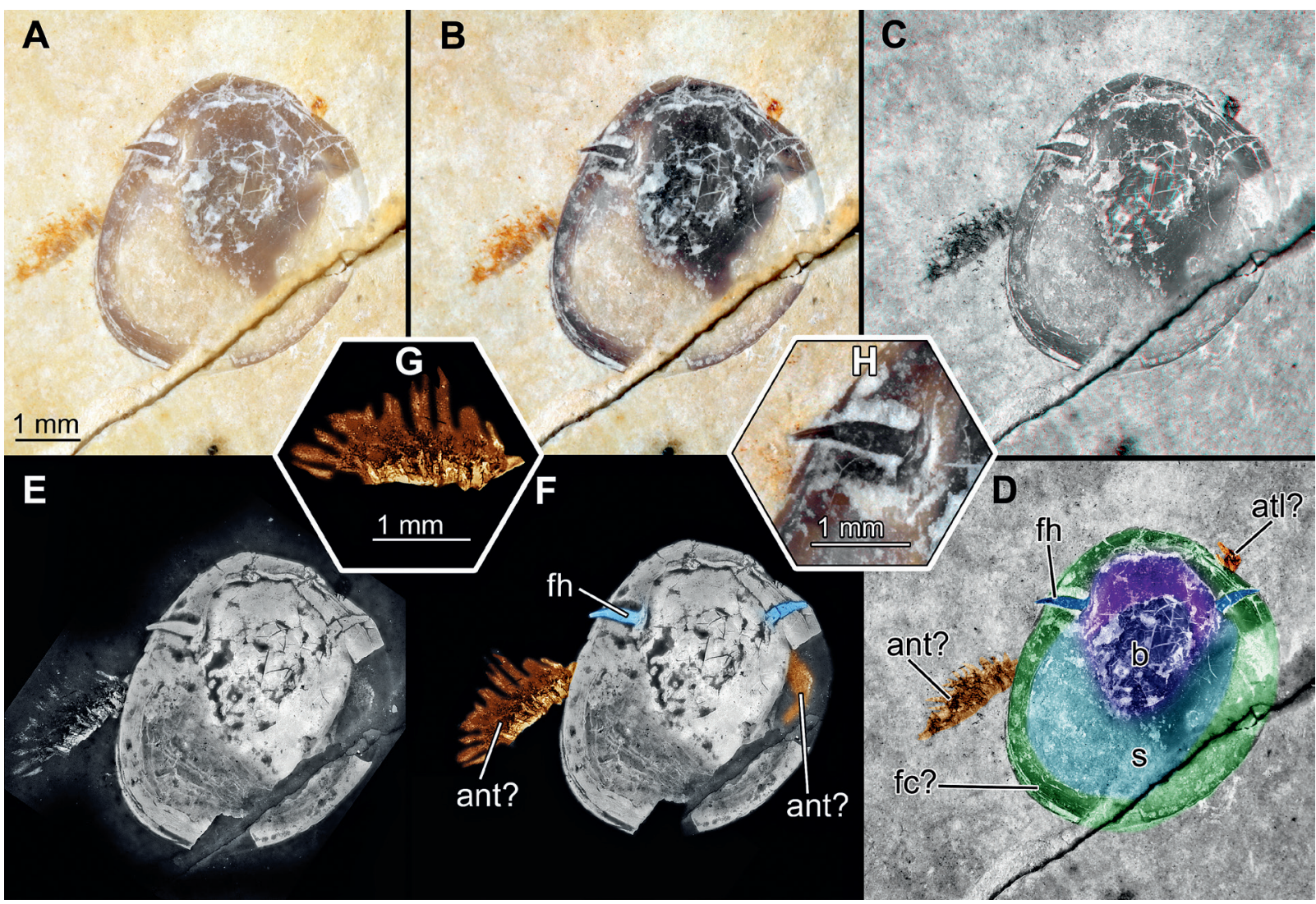

Fig. 1. Different photographic methods applied to the fossil specimen (SMNS 70409). A) Macro-photography under cross-polarized light. B) Like A, but with optimized histogram. C) Stereo-photography, please use red-cyan glasses. D) Highlighted version of C. E) Fluorescence photography. F) Highlighted version of E. G) Detail of appendage. H) Detail of horn. Abbreviations: ant? = antenna (orange); atl? = antennula (orange); $\mathrm{b}=$ body under the shield (dark blue); fc? = floating collar (green); $\mathrm{fh}=$ fronto-lateral horn (blue); $\mathrm{s}=$ shield rim (light blue).

stitched to panorama images using Adobe Photoshop CS3 or Elements 11. All images were optimized (sharpness, histogram, saturation) and dirt particles or background was removed manually using a lasso tool in Adobe Photoshop CS3.

\section{Presentation methods}

Interpretations of structures are presented by colormarked versions of the images. Structures apparent in the fluorescence and stereo-photography were marked with the lasso tool in Adobe Photoshop CS3 on a desaturated half image of the stereo image (Haug et al., 2012).

A simplified reconstruction of the fossil was assembled by mirroring missing structures (Haug et al., 2015d). For explaining structures, a virtual 3D model of a modern cirripede nauplius was reconstructed in
Blender 2.49 (Blender Foundation), based on drawings from Miller and Roughgarden (1994).

\section{Description of the specimen}

The specimen has a maximum length of $4.7 \mathrm{~mm}$. The main preserved part is an oval-shaped shield-like structure, with smaller structures protruding from it. This shield represents the maximum length of the specimen and has a maximum width of $3.1 \mathrm{~mm}$.

The texture, color and fluorescence capacities of the shield (and partly the protruding structures) resemble that of crustacean cuticle from the same Lagerstätte (which is different from most remains of fish, insects, echinoderms or molluscs). Different regions of the shield can be differentiated. A very central region is apparent in the color images as a darker area (Fig. 1A-B). 
This same area is also elevated in relief (Fig. 1C) and shows a stronger fluorescence (Fig. 1D). This region most likely represents the main body, partly compressed through the shield.

The central region extends latero-posterior and posterior into a thinner-appearing region. It is almost transparent under cross-polarized light; the matrix is visible (Fig. 1A-B). It appears to lack relief (Fig. 1C) and also shows a weaker fluorescence (Fig. 1D). Central region and extended region together are about 3.7 $\mathrm{mm}$ long and $2.5 \mathrm{~mm}$ wide.

Around the central region and the extended part of the shield a well set-off, ring-like region is apparent. It is set off from the central shield, i.e. in the anterior region by a distinct edge. In the posterior region the differentiation against the extended region is apparent due to a dark color of the ring (Fig. 1A-B), a slight positive relief and stronger fluorescence capacities.

The central shield bears a pair of spine-like protrusions. These spines originate antero-lateral from the edge between the central shield region and the ring. They are oriented mostly lateral, slightly anterior. They curve slightly backwards. The protrusions are slightly bellied proximally, but taper distally (Fig. 1H). The tip appears blunt; it is unclear whether this is the original condition or due to preservation. The protrusions reach slightly beyond the ring (Fig. 1A-D).

Three additional structures protrude from under the shield. The first is far anterior, also anterior to the spine-like protrusions. It is a short structure, more or less rectangular in outline. Originally, this was most likely a tube-shaped part of an appendage. It can be differentiated into two similar-appearing elements, most likely representing ringlets. Each of them bears a seta pointing antero-median. The structure can only be observed under cross-polarized light, it does not possess recognizable relief (Fig 1C) nor does it show fluorescence (Fig. 1D). It therefore differs from the preservation of the shield. The color is more orange and less glossy. Most likely it is not phosphatized (lack of fluorescence).

The second structure protrudes from under the shield laterally towards the latero-posterior (Fig. 1). The structure is preserved in different ways. Some areas resemble the preservation of the first protruding structure, show no fluorescence and appear orange. Other areas appear to be phosphatized (certain glossiness) and show fluorescence. Lastly, some areas are not at all apparent under cross-polarized light, but only under fluorescence. The central part of the structure appears elongate, originally tube-like, composed of several ele- ments (at least eight), originally ringlets (Fig. 1G). More distal elements are narrower than more proximal ones. Also more distal ones are slightly oblique towards the main axis of the structure, as the anterior (originally median?) dimension of each ringlet appears to be slightly longer than the posterior (originally lateral?) one. The supposed median sides of each ringlet appear drawn out into setae. The more proximal ones appear to bear a pair of setae, while the more distal ones appear to bear only a single seta. Ringlets are preserved more pronounced; their edges appear to be also phosphatized. Setae are only visible under fluorescence, especially the more distal regions of the setae (Fig. 1F$\mathrm{G})$. The overall organization of the structure resembles a multi-annulated exopod.

The third structure is preserved at an area, where apparently a part of the shield is broken off, with this revealing the structure, which would have been otherwise concealed. The preservation is rather weak, the structure only being apparent under fluorescence (Fig. $1 \mathrm{E}-\mathrm{F})$. It is elongate, most likely originally tube-shaped, tapering distally. It is curved, or partly folded or kinked. Proximal and distal region are both concealed by the shield. The surface appears to some degree granulose, with weakly outlined rings. Possibly the structure was rather weakly sclerotized originally, not being subdivided into discrete sclerites.

\section{Discussion}

\section{A possible interpretation of the fossil}

Although the specimen is small in comparison to other fossil larvae, at least from this Lagerstätte, and may not appear to bear many details, some of these details that are present allow a well-founded interpretation on the identity of the specimen. Texture and fluorescence capacities of the fossil resemble crustacean remains from the same deposits. Also from a structural point of view many interpretations that could come into mind, such as a fish scale, can be easily discarded. Specimens distantly resembling the fossil have been interpreted as possible remains of crustacean larvae (Haug et al., 2011a; 2014b). This seems also a likely interpretation of the new fossil.

When comparing the specimen to small-sized eucrustaceans it shows similarities to larval forms of barnacles and their relatives (Cirripedia). The pelagic larvae of cirripedes (nauplius larvae) are characterized by a pair of spine-like extensions of the anterior shield 


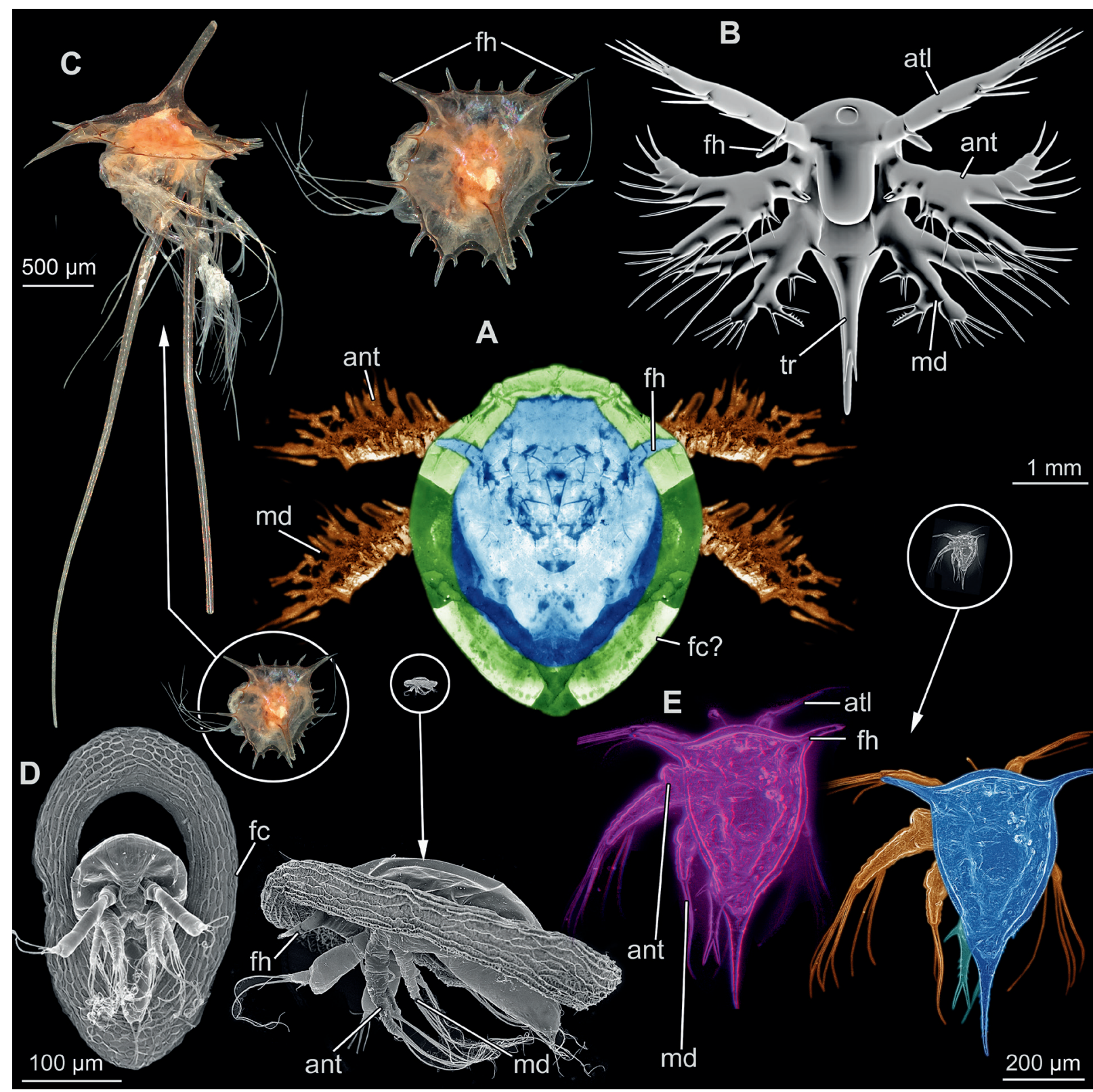

Fig. 2. Fossil and modern cirripede nauplii. A) Reconstruction of the fossil nauplius (center) and size comparison to modern counterparts (in circles). B) Model of a modern cirripede nauplius, not to scale. C) Macro-photography under cross-polarized light of modern lepadomorph nauplius (MNHN IU-2014-5478), lateral and dorsal view. D) Scanning electron microscopic photography of a modern rhizocephalan nauplius, please note the floating collar, lateral and ventral view. E) Fluorescence photography of modern balanomorph nauplius, stereo-projected (left, please use red-cyan glasses) and colour-marked version (right), dorsal view. Abbreviations: atl = antennula; ant $=$ antenna; $\mathrm{fc}=$ floating collar; $\mathrm{fh}=$ fronto-lateral horn; $\mathrm{md}=$ mandible; $\mathrm{tr}=($ initial $)$ trunk.

region, generally termed fronto-lateral horns (Høeg, 1987; Walker, 1992, Høeg and Møller, 2006; PérezLosada et al., 2009; 2012; Høeg et al., 2015). Historically, these fronto-lateral horns are an important char- acter that was first recognized by Thompson (1830). For a long time these structures were the only argument for the monophyly of Cirripedia (Høeg et al., 2015). Shape and relative position of the two spine-like 
extensions of the fossil (Figs. 1D, F, H, 2A) strongly resemble these fronto-lateral horns (Fig. 2B-E).

The preserved presumed appendage remains of the fossil would also well fit into this interpretation. Cirripede nauplii have three functional pairs of appendages: antennulae, antennae and mandibles (Fig. 2B-E; Chan et al., 2014; Høeg et al., 2014a; b; Kolbasov et al., 2014).

The second structure protruding from underneath the shield of the fossil specimen (Fig. 1D, F) strongly resembles the setose swimming exopods of antennae or mandibles of modern cirripede nauplii (Fig. 2B-E; e.g. Walossek et al., 1996). Due to the number of ringlets and setae, the structure on the fossil could represent an antenna, although an interpretation as a mandible cannot entirely be excluded.

The appendage remain on the other side of the fossil specimen (third structure; Fig. 1D) could represent the less well preserved antenna of the other body side, although it remains unclear whether it could then represent the endopod or the exopod. The further anterior, very incomplete appendage (first structure, Fig. 1D) is more difficult to interpret. The distinct ringlets could be understood as another exopod. The position would argue more for an interpretation as an antennula, yet, an antennula would not be organized into such discrete ringlets. In conclusion, the observed structures are compatible with the interpretation of the fossil as a cirripede nauplius.

\section{Difficulties with the interpretation}

When interpreting the fossil as a larval form of a barnacle or one of its relatives, three possible aspects need to be discussed:

\section{1) Size:}

The fossil is comparably large, at least for a nauplius, as most eucrustacean nauplii are rather small. Nauplii of representatives of Cirripedia are mostly in a size range between $200 \mu \mathrm{m}$ and $1 \mathrm{~mm}$ (Walossek et al., 1996; Walker, 2001; Høeg et al., 2004). Yet, also nauplii reaching astonishing sizes have been reported (Rybakov et al., 2003). In fact, shield sizes well over $1 \mathrm{~mm}$ seem not to be uncommon among modern forms (Fig. 2), resulting in total lengths of about $6 \mathrm{~mm}$ in Lepas anatifera (Moyse, 1987) or in Lepas pacifica (Ryusuke Kado, unpublished data).

The only fossil example of a possible cirripede larva is that of Rhamphoverritor reduncus (Briggs et al., 2005; see also further below). This larval specimen is not a nauplius, but may represent a settling stage, a so- called cypris, hence the stage following the last nauplius stage. Among modern forms the lengths of cypris larvae are difficult to infer from the literature. The fossil cypris has a total length of $4 \mathrm{~mm}$.

Crustaceans usually increase their size by up to $30 \%$ within a single molt (see discussion in Kutschera et al., 2012). The largest known cirripede eggs can reach up to $400 \mu \mathrm{m}$ (Korn et al., 2004). All extant representatives of Cirripedia develop through at most six naupliar stages (nauplius I - nauplius VI; Høeg et al., 2015). By calculating this example, the possible maximum size of a nauplius VI would result in an overall size of about $2 \mathrm{~mm}$.

However, the $30 \%$ rule seems to be less strict in certain crustaceans. The size increase between nauplius I and nauplius II in e.g. Lepas pectinata, is in average $150 \%$ (Moyse, 1987). Consequently, nauplius VI could reach overall lengths of more than $7 \mathrm{~mm}$. Taking this into account, a shield length of $4.7 \mathrm{~mm}$ in the fossil specimen described herein is quite reasonable (but see also further below).

\section{2) Position of the fronto-lateral horns:}

In most cirripede nauplii the fronto-lateral horns arise right from the fronto-lateral corners of the shield (Fig. $2 \mathrm{~B}-\mathrm{C}, \mathrm{E})$. This seems not to be the case in the fossil specimen. Here the shield rim is further drawn out, forming a set-off ring. Interpreting the horns differently is difficult, other possible structures such as frontal filaments, which occur within Thecostraca in all representatives (Walker, 1974; Grygier, 1987), are tiny and soft and hence unlikely to be preserved in a fossil. Also they are not horn like. In some naupliar stages, e.g. of the rhizocephalan Peltogaster paguri, the fronto-lateral horns are fully covered by a round extension of the shield (Fig. 2D; Høeg, unpublished data). These structures in the fossil specimen described herein are blunt at the tip and might therefore end in a pore as do true fronto-lateral horns. This observation supports the interpretation of the spine-like extensions as fronto-lateral horns and not as frontal filaments.

\section{3) Interpretation of the set-off ring:}

Examples of extensions of the shield, so-called 'floating collars', occur in some ingroups of Cirripedia, more precisely of Rhizocephala (exclusively parasitic forms). Such a floating collar has been considered as floatation device, enhancing the buoyancy of the nauplii (Veillet, 1943; Høeg et al., 2004). Such a type of floating collar (Fig. 2D) is known from the rhizocephalan ingroups Peltogastridae and Lernaeodiscidae, but could be part of the rhizocephalan ground pattern 
(Høeg et al., 2004; Glenner and Hebsgaard, 2006; Høeg et al., 2009).

The floating collar in rhizocephalans is shed separately from the rest of the cuticle and is made of exceedingly thin cuticle (Fig. 2D; Høeg et al., 2004). This seems to be quite different in the fossil specimen. Also in the fossil the possible floating collar seems to be positioned under the horns, while in modern forms it is over these. Still the structure and position of the ring in the fossil could still indicate an at least comparable function in the fossil. It could also be speculated that this could be indicative of a closer relationship to Rhizocephala.

\section{Other possible interpretations:}

\section{1) Malacostracan affinity:}

Most fossil larvae from the Solnhofen limestone have been identified as malacostracan larvae (see below). The fossil specimen described herein resembles in certain aspects a supposed malacostracan larva from the Solnhofen limestone (Haug et al., 2011a; 2014 b, fig. $32.2 \mathrm{~K})$. The specimen has been suggested to represent the remains of a shield of a decapod zoea. Could this interpretation also apply to the specimen described here? This is unlikely. The supposed fronto-lateral horns could be interpreted as lateral spines for example of a brachyuran zoea. In such a case we would expect additional spines, especially a rostral spine and a postero-dorsal spine (Wear, 1968; Martin, 1984; Haug et al., 2011a; Martin, 2014a). Also in other decapod zoeas especially a pronounced rostral spine should be expected. No breakage indicators are apparent that could indicate an absence due to preservation. Also the shape of the spines and their blunt tips would be unusual for a zoea larva. Therefore an interpretation of the new fossil as a zoea appears unlikely to us. Notably, already Haug et al. (2014b, p. 176) stated that the "systematic affinities remain uncertain until better-preserved specimens are found". The specimen from Haug et al. (2014b) could in the light of the new fossil described here also represent the conspecific cypris larva. The specimen should be reinvestigated for this aspect.

\section{2) Branchiopod affinity:}

There is also a certain resemblance of the fossil to the nauplius larva of representatives of Laevicaudata, an ingroup of Branchiopoda. These have a kind of spinelike extensions that represent the still immobile antennulae (Olesen, 2005). In contrast to larval representatives of Laevicaudata, in which these horns protrude from the ventral side of the head (Olesen, 2005; 2007), it seems that the horns in the fossil specimen described herein protrude from the dorsal side of the head shield, indicated by the relative position of the appendages (Fig. 1). Additionally, laevicaudatan nauplii have a distinct triangular shape of the anterior head which should be expected to be seen in the fossil if present. Yet, this is not the case. Also other characteristic features, such as a large, rounded labrum or caudal lobes, which are spine-like extensions posterior from the shield (Olesen, 2005 ; 2007) are not present in the fossil specimens. Yet, these could be more difficult to be visible, as the labrum is a soft ventral structure and the caudal lobes are comparably small. Lastly, most branhciopods are fresh water forms, only few groups of raptorial cladocerans have re-entered the marine realm, yet the original lagoons of the Solnhofen lithographic limestones must have represented a marine environment. Thus, a laevicaudatan or even a branchiopod affinity is very unlikely.

Summarizing: From the morphological point of view it seems likely that the here described fossil indeed represents a cirripede nauplius. It appears to possess a kind of floating collar that may point to a closer relationship to rhizocephalan cirripedes. The "main" shield would then measure about $3 \mathrm{~mm}$ and could molt into a cypris larva of the size as it is known for the fossil Rhamphoverritor reduncus with $4 \mathrm{~mm}$ length (Briggs et al., 2005). While the new larva is well in a possible size range for cirripede larvae, it clearly represents a giant form.

\section{Early fossil record of Cirripedia}

Cirripedes have a comparably good fossil record, at least concerning their adults. Rhamphoverritor reduncus from the Silurian (420 mya) is exceptional as only a possible cypris larva and a juvenile are known (Briggs et al., 2005). The species most likely represents the sister group to all other cirripedes (Høeg et al., 2009). There is generally a distinction of three groups within Cirripedia: Acrothoracica, Thoracica and Rhizocephala, with the latter two groups representing sister groups. The monophyly of each of the three groups is generally well supported. Yet, Thoracica is not as well characterized by morphological characters. It is therefore possible that any pedunculated fossil barnacle older than the presumed split between Rhizocephala and Thoracica (see below) might be situated phylogenetically below this point. 
Representatives of Acrothoracica have been reported as trace fossils from the Devonian (380 mya; Glenner et al., 1995). Molecular analyses give support for the origin of Thoracica in the Early Carboniferous (340 mya; Pérez-Losada et al., 2008). Based on the reconstruction of a co-evolution between rhizocephalans and anomalan crabs and molecular reconstructions of thoracican barnacles, representatives of Rhizocephala have been estimated to be present also since the Carboniferous (Walker, 2001; Boyko and Williams, 2009). As a consequence, all pedunculated fossil thoracicans older than 340 million years could be considered as representatives of the unnamed sister group to Acrothoracica. The first more direct fossil indications of rhizocephalans are feminized male crabs from the Miocene (4-23 mya; Feldmann, 1998). Also important to mention in this aspect: fossils of cirripedes are well known to occur in the lithographic limestones of southern Germany (Barthel et al., 1990; Nagler et al., 2017).

With this fossil record an interpretation of the here described fossil as the nauplius of a cirripede and even as a possible relative of Rhizocephala seems reasonable; at least it is not contradicted. The fossil, therefore, most likely represents the first fossil record of a cirripede nauplius. It also follows the general pattern that we seem to be more likely able to find especially giant larval forms as fossils.

\section{Giant larvae in metazoans}

The phenomenon of oversized larval forms has been reported from various metazoan groups. Yet, in many cases 'giant' is a matter of relation. An overview of giant larvae can be seen in Tab. 1.

As pointed out above, larvae of flying insects (Pterygota) are in their final larval stage often as large, sometimes larger, than the adult. Yet, as almost all insects have such comparably large larvae it is somehow difficult to consider any of them as a giant. Comparably larger larval size is mostly coupled to larger adult size.

Larvae of corals, sea anemones and others (Cnidaria) - planula - have an average maximum size of about $1 \mathrm{~mm}$ (Leloup, 1932). Yet, also specimens of up to 11 $\mathrm{mm}$ have been reported. Some of the even larger specimens with larva-like morphology already possess gonads (Molodtsova 2004; Stampar et al., 2015) and are therefore no longer larvae in the meaning of being immature.

The planktic larvae of marine snails and slugs (Gastropoda) - veliger - are usually below $1 \mathrm{~mm}$ in size before settling to a pelagic life. Yet, in some groups significantly larger forms are known. Veliger larvae of strombiids, coniids and cypraeiids have extremely elongated structures, the velum lobes. With these structures they reach sizes of about $5 \mathrm{~mm}$ (Hickman, 1999). Even larger forms of about 6-7 mm have been reported by Dawydoff (1940).

The early larval stage of ringed or segmented worms (Annelida) is plesiomorphically the trochophora. These are mostly below one millimeter in size before they metamorphose into forms with few body segments that carry appendages (chaetigers; often three such segments). Exceptions are special forms of phyllodocid larvae. Here the trunk grows significantly longer from the trochophora before undergoing metamorphosis. The spherical anterior region (hence the original trochophora) can reach sizes of up to $2 \mathrm{~mm}$; the trunk with up to 120 rudimentary segments can reach $10 \mathrm{~mm}$. Hence, the total length of these larvae reaches up to 12 mm (Tzetlin, 1998).

Larvae of peanut worms (Sipunculida) - pelagosphaera - have an average size of $300 \mu \mathrm{m}$ (Rice, 1967). Yet also significantly larger forms of up to $3.2 \mathrm{~mm}$ can sometimes be found in the plankton of open ocean regions (Rice, 1973).

Larvae of horseshoe worms (Phoronida) - actinotrocha - reach in general a maximum size of $0.7-0.9$ $\mathrm{mm}$. An unusually large phoronid larva has been reported by Temereva et al. (2006). This larval specimen was $3.5 \mathrm{~mm}$ long, thus 4-5 times larger than a "normal" actinotrocha larva.

Larvae of echinoderms (Echinodermata) are generally small, below $1 \mathrm{~mm}$ (e.g. Pawson, 1971). Yet, certain larvae of abyssal sea cucumbers (Holothuroidea) - auricularia - can reach sizes between 3 and $15 \mathrm{~mm}$ (Ohshima, 1911; Mortensen, 1913; 1921; Garstang, 1939). Also, the larva of the deep-sea starfish Luidia sarsi (Asteroidea) - bipinnaria - can reach body lengths of up to 25-35 mm (Domanski, 1984).

Larvae of acorn worms (Enteropneusta, Hemichordata) - tornaria - reach usually about $0.5-1 \mathrm{~mm}$ (Stiasny, 1928). Giant tornaria-like larvae (Planctosphaera pelagica) with a length of up to $28 \mathrm{~mm}$ have been found in the Atlantic and Pacific Ocean (Spengel, 1932; Hadfield and Young, 1983). Thus the found giant larvae are at least 20 times bigger than the "normal" larvae of Hemichordata. Yet, it is still controversial if Planctosphaera pelagica represents an ingroup of Enteropneusta (Hadfield and Young, 1983) or a separate group of hemichordates (Van der Horst, 1936).

Larvae of teleost fishes (Teleostei) are often quite large; few centimeters length is not uncommon. A very 
Table 1. Overview of giant larvae with larval terms and reported maximum sizes of their respective group or close relatives.

\begin{tabular}{|c|c|c|c|}
\hline Metazoan group (Representatives of) & Name of the larva & Maximum reported size & Average "usual" size \\
\hline Cnidaria & planula & $11 \mathrm{~mm}$ & $1 \mathrm{~mm}$ \\
\hline Gastropoda & veliger & $7 \mathrm{~mm}$ & $1 \mathrm{~mm}$ \\
\hline Annelida & trochophora & $12 \mathrm{~mm}$ & $3 \mathrm{~mm}$ \\
\hline Sipunculida & pelagosphaera & $3 \mathrm{~mm}$ & $0.3 \mathrm{~mm}$ \\
\hline Phoronida & actinotrocha & $3.5 \mathrm{~mm}$ & $0.7 \mathrm{~mm}$ \\
\hline Echinodermata (Holothuroidea) & auricularia & $15 \mathrm{~mm}$ & $1 \mathrm{~mm}$ \\
\hline Echinodermata (Asteroidea) & bipinnaria & $35 \mathrm{~mm}$ & $1 \mathrm{~mm}$ \\
\hline Hemichordata & tornaria-like & $28 \mathrm{~mm}$ & $0.7 \mathrm{~mm}$ \\
\hline Teleostei & leptocephalus & $300 / 1800 \mathrm{~mm}$ & $\mathrm{~mm}-\mathrm{cm}$ range \\
\hline Lissamphibia, extant & tadpole & $230 \mathrm{~mm}$ & few $\mathrm{cm}$ \\
\hline Lissamphibia, fossil & tadpole & $150 \mathrm{~mm}$ & few $\mathrm{cm}$ \\
\hline Achelata, extant & zoea (phyllosoma) & 80 mm (body length) & few mm \\
\hline Achelata, fossil & zoea (phyllosoma-like) & 100 mm (body length) & few mm \\
\hline Polychelida, extant & megalopa (eryoneicus) & $100 \mathrm{~mm}$ & few mm \\
\hline Polychelida, fossil & megalopa (eryoneicus-like) & $40 \mathrm{~mm}$ & few mm \\
\hline Stomatopoda, extant & erichthus, alima & $50 \mathrm{~mm}$ & few mm \\
\hline Stomatopoda, fossil & erichthus & $18 \mathrm{~mm}$ & few mm \\
\hline Anomala (Hippidae) & megalopa & $15 \mathrm{~mm}$ & few mm \\
\hline Dendrobranchiata (Aristidae) & zoea (cerataspis) & $12 \mathrm{~mm}$ & $1 \mathrm{~mm}$ \\
\hline Thecostraca (Facetotecta) & y-nauplius & $0.7 \mathrm{~mm}$ & $0.4 \mathrm{~mm}$ \\
\hline Thecostraca (Ascothoracida) & a-nauplius & $0.7 \mathrm{~mm}$ & $0.4 \mathrm{~mm}$ \\
\hline Thecostraca (Cirripedia) & c-nauplius & $7 \mathrm{~mm}$ & $0.5 \mathrm{~mm}$ \\
\hline
\end{tabular}

notable size is reached by larval eels (Anguilliformes) - leptocephalus - which regularly reach $300 \mathrm{~mm}$ in length (Miller, 2009), but sometimes even giant larvae longer than $1800 \mathrm{~mm}$ have been reported (Aron and McCrery, 1958; Tabeta, 1970; Kurogi et al., 2016).

Amphibian tadpoles (Lissamphibia) are all large compared to many other metazoan larvae, being in the range of several centimeters. Tadpoles of the frog Pseudis paradoxa reach sizes of up to $230 \mathrm{~mm}$ (Emerson, 1988). Also other species of Pseudis can reach quite a large tadpole sizes with up to $180 \mathrm{~mm}$ (Fabrezi et al., 2009). In these species the larva is also significantly larger than the adult. Fossil tadpoles with a size of up to $150 \mathrm{~mm}$ have been reported from the Miocene (Roček et al., 2006) and from the Lower Cretaceous (Chipman and Tchernov, 2002).

\section{Giant larvae in crustaceans}

Among numerous crustacean groups giant larvae have been reported, especially among decapods. Decapods usually have (at least) two larval phases: The pelagic zoea larvae swim with the outer locomotion branches (exopods) of their thoracopods. This phase may include up to ten stages. The zoea is followed by the megalopa, which mediates the transition between the pelagic larva and the benthic juvenile. Most megalopae have lost their exopods on the thoracopods and swim with their pleopods. In many groups there is only a single megalopa stage. Sometimes larvae show a kind of mixed morphologies somewhere "between" zoea and megalopa. The latest zoea as well as the megalopa usually measure only few millimeters in total length. Yet, there are quite some exceptions:

Zoea larvae of prawns (Dendrobranchiata) are usually small with shield lengths rarely reaching $1 \mathrm{~mm}$. Yet, within Aristidae zoea larvae formerly addressed as "Cerataspis monstrosa" reach shield lengths of almost $12 \mathrm{~mm}$ (Bracken-Grissom et al., 2012).

Polychelidan lobsters (Polychelida) only have a short zoea phase (Torres et al., 2014), but have several megalopa stages that reach astonishing sizes. These eryoneicus larvae reach sizes of more than $100 \mathrm{~mm}$ in length (Martin, 2014b; Eiler et al., 2016). Fossil forms that show some similarities to modern forms and also an increased size have been reported from the Jurassic Solnhofen limestones (Eiler and Haug, 2016), and from the Cretaceous limestones of Lebanon (Haug et al., 2015a).

Achelatan lobsters (Achelata) develop through a characteristic type of zoea larva, the phyllosoma (Palero et al., 2014). Phyllosoma larvae have been recog- 
nized as giant larvae frequently in the literature. They can reach up to $80 \mathrm{~mm}$ in body length, with their thin legs extending even longer (Guérin, 1822; Richters, 1873; Johnson, 1951; Sims, 1964; Sims and Brown, 1968). Phyllosoma larvae most likely represent the largest decapod larvae (Palero et al., 2014). As a consequence, also the megalopa larvae of achelatans (nisto and puerulus larvae) are significantly larger than other types of megalopa larvae. Giant phyllosoma larvae have been reported from the fossil record with body length up to $100 \mathrm{~mm}$. Besides "typical phyllosoma larvae (Polz, 1972; 1973; 1984; 1987; 1995; 1996; Haug et al., 2009; 2011a), large nisto larvae (Audo et al., 2014; Haug and Rudolf, 2015), but also transitory forms with a "mixed" morphology of phyllosoma and post-phyllosoma stages have been reported (Haug et al., 2013b; Haug and Haug, 2013, 2016).

Larvae of false sand crabs (Hippidae) usually reach a total length of $2 \mathrm{~mm}$. A single specimen has been reported to have reached $15 \mathrm{~mm}$ in total (Martin and Ormsby, 1991). Yet recently more material turned up demonstrating that reaching such a size may be quite more common among false sand crabs than expected (Rudolf et al., 2016).

While mantis shrimps (Stomatopoda) are not decapods, they show certain similarities to them including various aspects of their larval development. Their later larva can be roughly seen as the functional equivalent to the megalopa larva in decapods. Depending on the specific ingroup these larvae are of the alima-type or of the erichtus-type. Both reach sizes of several centimeters. Alima-type larvae have been known to reach up to $5 \mathrm{~mm}$ (Ahyong et al., 2014). Just recently new very large erichthus-type larvae have been described (Haug et al., 2016). Erichthus-type larvae have also been described from the Jurassic lithographic limestones from Germany with up to $18 \mathrm{~mm}$ (Haug et al., 2008; 2015b). Notably, giant fossil larvae from the Triassic Hallstatt limestone from Austria with shield lengths of $13 \mathrm{~mm}$ show certain characters of the mantis shrimp larvae, and also similarities to the false sand crab larvae (Hyžný et al., 2016).

\section{The possible function of giant larvae}

Generally, we can distinguish between two types of giant larva: Type one are facultative giant larvae, type two are obligate giant larvae.

Type one giant larvae occur in species that usually have "normal-sized" larva, but in which from time to time giant individuals occur. Here 'giant' is meant in comparison to individuals of the same species. Such giant larvae must be understood as caused by external factors. A rather simple and probably widespread case for causing such instances is the simple absence of a settling trigger. Many larvae need specific chemical environmental cues that indicate an advantageous habitat for the benthic juvenile/adult. If such cues are absent, larvae can simply continue to grow without metamorphosing. Also other abiotic factors have been suggested to be important in this aspect. For example, temperature and shifts in photoperiod length seem to influence the development of tadpoles in the direction to giant tadpoles (Emerson, 1988; Fabrezi et al., 2010).

It has also been suggested that giant size of larvae may be a consequence of a physiological defect. Such larvae often already develop adult organs, e.g., primordial gonads (Temereva et al., 2006). A disruption in thyroid hormone production before metamorphosis has been suggested as reason for this phenomenon (Emerson, 1988; Shi and Hayes, 1994; Schreiber et al., 2001; Yun-Bo et al., 2001; Ogielska and Kotusz, 2004; RotNikcevic and Wassersug, 2004; Roček et al., 2006).

Parasites have also been identified as causes of suppressing a metamorphosis trigger, with this leading to giant-sized larval forms. Insect larvae infected with parasites molt more often than non-parasitized larvae and die as giant larvae (Fisher, 1963). Hormones increasing the juvenile activity of the host cause this exceptional development. In this way, the parasite gets a larger host by its hormone manipulation (Dawkins, 1990).

Type two giant larvae are cases in which representatives of all individual species (or larger group) develop through larval forms that grow significantly larger than the larvae of closely related groups (Fabrezi and Goldberg, 2009). This also leads to a prolonged larval phase. Such a prolonged larval span can enhance the capability for long-distance dispersal in the planktic phase of some species of different molluscs, echinodermatans, or achelatan lobsters (Domanski, 1984).

In this context, one could think of abyssal gigantism (Herring, 2001) also as explanation for giant larvae. Mainly crustaceans have been reported to reach a larger size in deep-sea environments than their relatives in shallow waters (King and Butler, 1985; Mauchline, 1995; Chapelle and Peck, 1999). Low temperature and restricted food availability in deep seas are thought to decrease growth rates, but to increase longevity and the time span to reach sexual maturity (Nybakken, 2001). Hence, it seems to affect juvenile instead of larval development, not necessarily leading to large larvae. Abyssal gigantism has been proposed for the loricifer- 
an Higgins larvae by Gad (2005). Yet, these forms are in fact paedomorphic adults and therefore not larvae.

Giant larvae of type two often bear structural specializations. In many giant crustacean larvae spines or extensions of the shield are necessary to increase the buoyancy (Eiler et al., 2016; Haug et al., 2016). Eel larvae deposit large amounts of glycosaminoglycans in their musculature increasing their swimming ability due to the enhanced skeletal stability (Bishop and Torres, 1999). Giant acorn worm larvae are adapted to a prolonged larval span by relatively larger feeding structures to process more food (Damas and Stiasny, 1961; Strathmann and Bonar, 1976).

Interestingly, we can even identify combined cases of type one and type two giant larvae. Eel larvae are in some species $300 \mathrm{~mm}$ in average and with this significantly larger than many other fish larvae and representing cases of giant larvae of type 2. Yet, among these even larger larval individuals are known of $1800 \mathrm{~mm}$, with this being cases of type 1 , representing a kind of super-giant larva.

\section{Interpretation of the present case}

Cirripede nauplius larvae represent dispersal and growth stages that can last short or long (Høeg et al., 2015). A short larval span is only possible if the larvae find a suitable habitat in close distance to their parents (Buhl-Mortensen and Høeg, 2006). In environments that have a patchily distributed settlement habitat, it is more likely that larger larvae are adapted for long-distance and long-time dispersal as it has been reported for some deep-sea cirripedes (Buhl-Mortensen and Høeg, 2006; Yorisue et al., 2013). The Solnhofen limestone Lagerstätte represents a Jurassic back-reef lagoon (Barthel et al., 1990), where suitable habitats for cirripedes might have been rare and nauplii must have searched for a long time for their settlement site. Additionally, in modern cirripedes, lecithotrophic nauplii are more rounded and larger than planctotrophic nauplii, but show more simple setae and reduced development of the appendages and the labrum (Anderson, 1965; 1987; Høeg et al., 2004). However, the fossil specimen described herein is generally large and rounded, but show at the same time well developed appendages and possibly a well developed labrum (Fig. 1D). Hence, it is likely that the fossil specimen described herein could store lipids and ingest food for its metabolic needs at the same time to survive a long-term dispersal phase. As pointed out above, modern cirripedes seem to be restricted in the number of molts as a naup- lius. It seems therefore most likely that the larva represents a case two, i.e. an obligate dispersal larva. This is also in accordance with a supposed floating rim of the shield.

It might be seen as special that we have a highly specialized nauplius larva as the first fossil report of a cirripede nauplius. Yet, it is in overall concordance that we tend to find giant larvae. Moreover, the finding is also important because it provides us a rare look into the Mesozoic plankton of which our knowledge is still very incomplete.

\section{Acknowledgements}

CN, CH and JTHa are kindly supported by J. Matthias Starck, Munich. Long-standing support is provided by Michael Fecke, who found the specimen. Special thanks to Ryusuke Kado, Fred Schram and an unknown reviewer for comments on a former version of this manuscript. We thank all people involved in providing open source, open access or low cost software, such as OpenOffice, Blender, CombineZM, CombineZP, Image Analyzer, ImageJ, Microsoft Image Composite Editor. $\mathrm{CN}$ is gratefully funded by the Studienstiftung des deutschen Volkes with a $\mathrm{PhD}$ fellowship. JTHø is funded by the Carlsberg Foundation. $\mathrm{CH}$ was supported via the Bavarian Equal Opportunities Sponsorship of the LMU. The German Research Foundation (DFG) under Ha 6300/3-1 kindly funded JTHa. The research trip of CN to Copenhagen and those of $\mathrm{CH}$ and JTHa to Paris were funded by grants from the European Commission's (FP 6, FP7) Integrated Infrastructure Initiative program SYNTHESYS (FRTAF-5175, FR-TAF-5181, DK-TAF-5423).

\section{References}

Ahyong ST, Haug JT, Haug C. 2014. Stomatopoda. Pp. 185-187 in: Martin JW, Olesen J, Høeg JT, eds, Atlas of Crustacean Larvae. Johns Hopkins University Press, Baltimore.

Anderson DT. 1965. Embryonic and larval development and segment formation in Ibla quadrivalivis Cuvier (Cirripedia). Australian Journal of Zoology 13: 1-16.

Anderson D. T. 1987. The larval musculature of the barnacle Ibla quadrivalvis Cuvier (Cirripedia, Lepadomorpha).Proceedings of the Royal Society of London B: Biological Sciences 231: 313-338.

Anger K. 2001. The biology of decapod crustacean larvae. AA Balkema Publishers, Lissabon.

Aron W, McCrery P. 1958. Preliminary report of midwater trawling studies in the North Pacific Ocean. Technical Report Department for Oceanography of the University of Washington 58: 56-60.

Audo D, Charbonnier S, Schweigert G, Martin JS. 2014. New eryonid crustaceans from the Late Jurassic Lagerstätten of Cerin (France), Canjuers (France), Wattendorf (Germany) and Zandt (Germany). Journal of Systematic Palaeontology 12: $459-479$. 
Barthel KW, Swinburne NH, Morris SC. 1990. Solnhofen. A Study in Mesozoic Palaeontology. CUP Archive, Cambridge.

Bishop R, Torres J. 1999. Leptocephalus energetics: metabolism and excretion. Journal of Experimental Biology 202: 24852493.

Bracken-Grissom HD, Felder DL, Vollmer NL, Martin JW, Crandall KA. 2012. Phylogenetics links monster larva to deep-sea shrimp. Ecology and Evolution 2: 2367-2373.

Boyko CB, Williams JD. 2009. Crustacean parasites as phylogenetic indicators in decapod evolution. Decapod Crustacean Phylogenetics 18: 197-220.

Briggs DEG, Sutton MD, Siveter DJ, Siveter DJ. 2005. Metamorphosis in a Silurian barnacle. Proceedings of the Royal Society of London B: Biological Sciences 272: 2365-2369.

Buhl-Mortensen L, Høeg JT. 2006. Reproduction and larval development in three scalpellid barnacles, Scalpellum scalpellum (Linnaeus 1767), Ornatoscalpellum stroemii (M. Sars 1859) and Arcoscalpellum michelottianum (Seguenza 1876), Crustacea: Cirripedia: Thoracica): implications for reproduction and dispersal in the deep sea. Marine Biology 149: 829-844.

Chan BK, Høeg JT, Kado R. 2014. Thoracica. Pp. 116-121 in: Martin JW, Olesen J, Høeg JT, eds, Atlas of Crustacean Larvae. Johns Hopkins University Press, Baltimore.

Chapelle G, Peck LS. 1999. Polar gigantism dictated by oxygen availability. Nature 399: 114-115.

Chipman AD, Tchernov E. 2002. Ancient ontogenies: larval development of the Lower Cretaceous anuran Shomronella jordanica (Amphibia: Pipoidea). Evolution \& Development 4: 86-95.

Cowen RK, Sponaugle S. 2009. Larval dispersal and marine population connectivity. Annual Review of Marine Science 1: 443-466.

Damas D, Stiasny G. 1961. Les larves planetoniques d'Enteropneustes (Tornaria et Planetosphaera). Memoire de l'Academie royale de Belgique C1 des Sciences 15: 1-70.

Dawkins R. 1990. Parasites, desiderata lists and the paradox of the organism. Parasitology 100: 63-73.

Dawydoff C. 1940. Quelques Véligères géantes de Prosobranches provenant de la Mer de Chine. Bulletin Biologique de la France et de la Belgique 74: 497-507.

Domanski P. 1984. Giant larvae: Prolonged planktonic larval phase in the asteroid Luidia sarsi. Marine Biology 80: 189195.

Eiler SM, Haug JT. 2016. Larval development of fossil polychelidan crustaceans, exemplified by the 150 million years old species Palaeopentacheles roettenbacheri. Neues Jahrbuch für Geologie und Paläontologie-Abhandlungen 279: 295310.

Eiler SM, Haug C, Haug JT. 2016. Detailed description of a giant polychelidan Eryoneicus-type larva with modern imaging techniques. Spixiana 39: 39-60.

Emerson SB. 1988. The giant tadpole of Pseudis paradoxa. Biological Journal of the Linnean Society 34: 93-104.

Fabrezi M, Goldberg J. 2009. Heterochrony during skeletal development of Pseudis platensis (Anura, Hylidae) and the early offset of skeleton development and growth. Journal of Morphology 270: 205-220.

Fabrezi M, Quinzio SI, Goldberg J. 2009. Giant tadpole and delayed metamorphosis of Pseudis platensis Gallardo, 1961 (Anura, Hylidae). Journal of Herpetology 43: 228-243.
Fabrezi M, Quinzio SI, Goldberg J. 2010. The ontogeny of Pseudis platensis (Anura, Hylidae): heterochrony and the effects of larval development on postmetamorphic life. Journal of Morphology 271: 496-510.

Feldmann RM. 1998. Parasitic castration of the crab, Tumidocarcinus giganteus Glaessner, from the Miocene of New Zealand: coevolution within the Crustacea. Journal of Paleontology 72: 493-498.

Fisher FM. 1963. Production of host endocrine substances by parasites. Annals of the New York Academy of Sciences 113: 63-73.

Gad G. 2005. Giant Higgins-larvae with paedogenetic reproduction from the deep sea of the Angola Basin-evidence for a new life cycle and for abyssal gigantism in Loricifera? Organisms Diversity \& Evolution 5: 59-75.

Garstang W. 1939. Memoirs: Spolia Bermudiana. On a remarkable new typ of Auricularia larva (A. bermudensis n. sp.). Journal of Cell Science 2: 321-345.

Giese A, Pearse J. 1975. Reproduction of marine invertebrates. Academic Press, San Diego.

Glenner H, Hebsgaard MB. 2006. Phylogeny and evolution of life history strategies of the parasitic barnacles (Crustacea, Cirripedia, Rhizocephala). Molecular Phylogenetics and Evolution 41: 528-538.

Glenner H, Grygier MJ, Høeg JT, Jensen P, Schram F. 1995. Cladistic analysis of the Cirripedia Thoracica. Zoological Journal of the Linnean Society 114: 365-404.

Grygier MJ. 1987. New records, external and internal anatomy, and systematic position of Hansen's y-larvae (Crustacea: Maxillopoda: Facetotecta). Sarsia 72: 261-278.

Guérin F. 1822. Crustacés et arachnides. Voyage autour du monde, exécuté par Ordre du Roi, sur la corvette de Sa Majesté, la Coquille, pendant les années 2: 9-319.

Hadfield M, Young R. 1983. Planctosphaera (Hemichordata: Enteropneusta) in the Pacific Ocean. Marine Biology 73: 151-153.

Haug C, Ahyong ST, Wiethase JH, Olesen J, Haug JT. 2016. Extreme morphologies of mantis shrimp larvae Nauplius 24: e2016020.

Haug C, Haug JT, Maas A, Waloszek D. 2014a. Fossil larvae (head larvae, nauplii and others) from the Cambrian in Orsten preservation. Pp. 17-27 in: Martin JW, Olesen J, Høeg JT, eds, Atlas of Crustacean Larvae. Johns Hopkins University Press, Baltimore.

Haug C, Haug JT, Waloszek D. 2009. Neues zur Krebsfauna der süddeutschen Plattenkalke. Archaeopteryx 27: 31-37.

Haug C, Kutschera V, Ahyong ST, Vega FJ, Maas A, Waloszek D, Haug JT. 2013a. Re-evaluation of the Mesozoic mantis shrimp Ursquilla yehoachi based on new material and the virtual peel technique. Palaeontologia Electronica 16: 14.

Haug C, Nyborg T, Kovalchuk G, Nyborg B, Haug JT. 2015d. Pushing the limits to the north - a fossil mantis shrimp from Oregon, USA. Neues Jahrbuch für Geologie und Paläontologie-Abhandlungen 278: 281-290.

Haug C, Van Roy P, Leipner A, Funch P, Rudkin DM, Schöllmann L, Haug JT. 2012. A holomorph approach to xiphosuran evolution - a case study on the ontogeny of Euproops. Development Genes and Evolution 222: 253-268.

Haug C, Wiethase JH, Haug JT. 2015b. New records of Mesozoic mantis shrimp larvae and their implications on modern larval traits in stomatopods. Palaeodiversity 8: 121-133. 
Haug JT, Haug C. 2013. An unusual fossil larva, the ontogeny of achelatan lobsters, and the evolution of metamorphosis. Bulletin of Geosciences 88: 195-206.

Haug JT, Haug C. 2015. Crustacea. Pp. 1-37 in: Wanninger A, ed, Evolutionary Developmental Biology of Invertebrates, Springer, Wien.

Haug JT, Haug C. 2016. "Intermetamorphic" developmental stages in 150 million-year-old achelatan lobsters - The case of the species tenera. Arthropod Structure \& Development 45: 108-121.

Haug JT, Haug C. 2017. A new glimpse on Mesozoic zoo-plankton - 150 million years old lobster larvae. PeerJ. 5: e2966.

Haug JT, Rudolf NR. 2015. A nisto larva of an Eocene slipper lobster (Neoscyllarida). Palaeodiversity 8: 113-119.

Haug JT, Ahyong ST, Haug C. 2014b. Fossil malacostracan larvae. Pp. 176-180 in: Martin JW, Olesen J, Høeg JT, eds, Atlas of Crustacean Larvae. Johns Hopkins University Press, Baltimore.

Haug JT, Audo D, Charbonnier S, Haug C. 2013b. Diversity of developmental patterns in achelate lobsters - today and in the Mesozoic. Development Genes and Evolution 223: 363-373.

Haug JT, Audo D, Haug C, Saad PA, Petit G, Charbonnier S. 2015a. Unique occurrence of polychelidan lobster larvae in the fossil record and its evolutionary implications. Gondwana Research 282: 869-874.

Haug JT, Haug C, Ehrlich M. 2008. First fossil stomatopod larva (Arthropoda: Crustacea) and a new way of documenting Solnhofen fossils (Upper Jurassic, Southern Germany). Palaeodiversity 1: 103-109.

Haug JT, Haug C, Kutschera V, Mayer G, Maas A, Liebau S, Castellani C, Wolfram U, Clarkson ENK, Waloszek D. 2011b. Autofluorescence imaging, an excellent tool for comparative morphology. Journal of Microscopy 244: 259-272.

Haug JT, Haug C, Waloszek D, Schweigert G. 2011a. The importance of lithographic limestones for revealing ontogenies in fossil crustaceans. Swiss Journal of Geosciences 104: 85-98.

Haug JT, Martin JW, Haug C. 2015c. A 150-million-year-old crab larva and its implications for the early rise of brachyuran crabs. Nature Communications 6: 6417.

Herring P. 2001. The biology of the deep ocean. New York, OUP Oxford.

Hickman CS. 1999. Larvae in invertebrate development and evolution. Pp. 22-60 in: Hall B, Wake M, eds, The origin and evolution of larval forms, Academic Press, San Diego.

Høeg JT. 1987. The relation between cypris ultrastructure and metamorphosis in male and female Sacculina carcini (Crustacea, Cirripedia). Zoomorphology 107: 299-311.

Høeg JT, Møller OS. 2006. When similar beginnings lead to different ends: constraints and diversity in cirripede larval development. Invertebrate Reproduction \& Development 49: 125-142.

Høeg JT, Chan BKK, Martin JW. 2014a. Introduction to the Thecostraca. Pp. 97-99 in: Martin JW, Olesen J, Høeg JT, eds, Atlas of Crustacean Larvae. Johns Hopkins University Press, Baltimore.

Høeg JT, Chan BKK. Martin JW. 2014b. Rhizocephala. Pp. 111115 in: Martin JW, Olesen J, Høeg JT, eds, Atlas of Crustacean Larvae. Johns Hopkins University Press, Baltimore.

Høeg JT, Deutsch J, Chan BKK, Semmler H. 2015. "Crustacea": Cirripedia. Pp. 153-181 in: Wanninger A, ed, Evolutionary
Developmental Biology of Invertebrates 4. Springer, Wien.

Høeg JT, Møller OS, Rybakov A. 2004. The unusual floatation collar around nauplii of certain parasitic barnacles (Crustacea: Cirripedia: Rhizocephala). Marine Biology 144: 483-492.

Høeg JT, Pérez-Losada M, Glenner H, Kolbasov GA, Crandall KA. 2009. Evolution of morphology, ontogeny and life cycles within the Crustacea Thecostraca. Arthropod Systematics and Phylogeny 67: 199-217.

Hyžný M, Haug C, Haug JT. 2016. Mesoprosopon triasinum from the Triassic of Austria revisited: The oldest eumalacostracan larva known to date and its significance for interpreting fossil cycloids. Gondwana Research 37: 86-97.

Johnson MW. 1951. A giant phyllosoma larva of a loricate crustacean from the tropical Pacific. Transactions of the American Microscopical Society 70: 274-278.

King M, Butler A. 1985. Relationship of life-history patterns to depth in deep-water caridean shrimps (Crustacea: Natantia). Marine Biology 86: 129-138.

Kolbasov GA, Chan BKK, Høeg JT. 2014. Acrothoracica. Pp107-110 in: Martin JW, Olesen J, Høeg JT, eds, Atlas of Crustacean Larvae. Johns Hopkins University Press, Baltimore.

Korn OM, Shukalyuk AI, Trofimova AV, Isaeva VV. 2004. Reproductive stage of the life cycle in the rhizocephalan barnacle Polyascus polygenea (Crustacea: Cirripedia). Russian Journal of Marine Biology 30: 328-340.

Kurogi H, Chow S, Yanagimoto T, Konishi K, Nakamichi R, Sakai K, Ohkawa T, Saruwatari T, Takahashi M, Ueno Y. 2016. Adult form of a giant anguilliform leptocephalus Thalassenchelys coheni Castle and Raju 1975 is Congriscus megastomus (Günther 1877). Ichthyological Research 63: 239-246.

Kutschera V, Maas A, Waloszek D, Haug C, Haug JT. 2012. Restudy of larval stages of Amphionides reynaudii (Malacostraca: Eucarida) with modern imaging techniques. Journal of Crustacean Biology 32: 916-930.

Leloup E. 1932. Cerianthaires de l'Ocean Atlantic. Bulletin du Musee Royal d'Histoire Naturelle de Belgique 8: 1-19.

Martin JW. 1984. Notes and bibliography on the larvae of xanthid crabs, with a key to the known xanthid zoeas of the western Atlantic and Gulf of Mexico. Bulletin of Marine Science 34: $220-239$.

Martin JW. 2014a. Brachyura. Pp. 296-310 in: Martin JW, Olesen J, Høeg JT, eds, Atlas of Crustacean Larvae. Johns Hopkins University Press, Baltimore.

Martin JW. 2014b. Polychelida. Pp. 279-282 in: Martin JW, Olesen J, Høeg JT, eds, Atlas of Crustacean Larvae. Johns Hopkins University Press, Baltimore.

Martin JW, Ormsby B. 1991. A large brachyuran-like larva of the Hippidae (Crustacea: Decapoda: Anomura) from the Banda Sea, Indonesia: the largest known zoea. Proceedings of the Biological Society of Washington 104: 561-568.

Martin JW, Olesen J, Høeg JT. 2014. The crustacean nauplius. Pp. 8-16 in: Martin JW, Olesen J, Høeg JT, eds, Atlas of Crustacean Larvae. Johns Hopkins University Press, Baltimore.

Mauchline J. 1995. Bathymetric adaptations of life history patterns of congeneric species (Euchaeta: Calanoida) in a 2000 $\mathrm{m}$ water column. ICES Journal of Marine Science: Journal $d u$ Conseil 52: 511-516.

Miller KM, Roughgarden J. 1994. Descriptions of the larvae of Tetraclita rubescens and Megabalanus californicus with a comparison of the common barnacle larvae of the central 
California coast. Journal of Crustacean Biology 14: 579-600.

Miller MJ. 2009. Ecology of anguilliform leptocephali: remarkable transparent fish larvae of the ocean surface layer. AquaBioScience Monographs 2: 1-94.

Molodtsova T. 2004. On the taxonomy and presumable evolutionary pathways of planktonic larvae of Ceriantharia (Anthozoa, Cnidaria). Coelenterate Biology 2003: 261-266.

Mortensen T. 1913. Die Echinodermenlarven der Deutschen Südpolar-Expedition 1901-1903. Deutsche Südpolar Expedition 14: 69-111.

Mortensen T. 1921. Studies of the development and larval forms of echinoderms. Gad, Copenhagen.

Moyse J. 1987. Larvae of lepadomorph barnacles. Pp. 329-362 in: Southward AJ, ed, Barnacle Biology, A.A. Balkema, Rotterdam.

Nagler C, Haug JT, Glenner H, Buckeridge J. 2017. Litholepas klausreschi gen. et sp. nov., a new neolepadine barnacle (Cirripedia, Thoracica) on a sponge from the Upper Jurassic lithographic limestones of southern Germany. Neues Jahrbuch für Geologie und Paläontologie Abhandlungen 284: 29-42.

Nybakken JW. 2001. Marine biology: an ecological approach. San Francisco, Benjamin \& Cummings.

Ogielska M, Kotusz A. 2004. Pattern and rate of ovary differentiation with reference to somatic development in anuran amphibians. Journal of Morphology 259: 41-54.

Olesen J. 2005. Larval development of Lynceus brachyurus (Crustacea, Branchiopoda, Laevicaudata): Redescription of unusual crustacean nauplii, with special attention to the molt between last nauplius and first juvenile. Journal of Morphology 264: 131-148.

Olesen J. 2007. Monophyly and phylogeny of Branchiopoda, with focus on morphology and homologies of branchiopod phyllopodous limbs. Journal of Crustacean Biology 27: 165-183.

Ohshima H. 1911. Note on a gigantic form of auricularia allied to A. nudibranchiata Chun. Annotationes Zoologicae Japonenses 7: 347-352.

Palero F, Guerao G, Hall M, Chan TY, Clark PF. 2014. The 'giant phyllosoma' are larval stages of Parribacus antarcticus (Decapoda: Scyllaridae). Invertebrate Systematics 28: 258-276.

Passano L. 1961. The regulation of crustacean metamorphosis. American Zoologist 3: 89-95.

Pawson DL. 1971. Second New Zealand Record of the holothurian giant larva Auricularia nudibranchiata Chun. New Zealand Journal of Marine and Freshwater Research 5: 381-387.

Pérez-Losada M, Harp M, Høeg JT, Achituv Y, Jones D, Watanabe H, Crandall KA. 2008. The tempo and mode of barnacle evolution. Molecular Phylogenetics and Evolution 46: 328-346.

Pérez-Losada M, Høeg JT, Crandall KA. 2009. Remarkable convergent evolution in specialized parasitic Thecostraca (Crustacea). BMC Biology 7: 15.

Pérez-Losada M, Høeg JT, Crandall KA. 2012. Deep phylogeny and character evolution in Thecostraca (Crustacea: Maxillopoda). Integrative and Comparative Biology 2012: ics051.

Polz H. 1971. Eine weitere Phyllosoma-Larve aus den Solnhofener Plattenkalken. Neues Jahrbuch für Geologie und Paläontologie Monatshefte 8: 474-488.

Polz H. 1972. Entwicklungsstadien bei fossilen Phyllosomen (Form A) aus den Solnhofener Plattenkalken. Neues Jahrbuch für Geologie und Paläontologie Monatshefte 12: 678-689.
Polz H. 1973. Entwicklungsstadien bei fossilen Phyllosomen (Form B) aus den Solnhofener Plattenkalken. Neues Jahrbuch für Geologie und Paläontologie Monatshefte 15: 284296.

Polz H. 1984. Krebslarven aus den Solnhofener Plattenkalken. Archaeopteryx 2: 30-40.

Polz H. 1987. Zur Differenzierung der fossilen Phyllosomen (Crustacea, Decapoda) aus den Solnhofener Plattenkalken. Archaeopteryx 5: 23-32.

Polz H. 1995. Ein außergewöhnliches Jugendstadium eines palinuriden Krebses aus den Solnhofener Plattenkalken. Archaeopteryx 13: 67-74.

Polz H. 1996. Eine Form-C-Krebslarve mit erhaltenem Kopfschild (Crustacea, Decapoda, Palinuroidea) aus den Solnhofener Plattenkalken. Archaeopteryx 14: 43-50.

Rice ME. 1967. A comparative study of the development of Phascolosoma agassizii, Golfingia pugettensis, and Themiste pyroides with a discussion of developmental patterns in the Sipuncula. Ophelia 4: 143-171.

Rice ME. 1973. Morphology, behavior, and histogenesis of the pelagosphera larva of Phascolosoma agassizii (Sipuncula). Smithsonian Contributions to Zoology 132: 1-51.

Richters F. 1873. Die Phyllosomen: Ein Beitrag zur Entwicklungsgeschichte der Loricaten. Wilhelm Engelmann, Leipzig.

Roček Z, Böttcher R, Wassersug R. 2006. Gigantism in tadpoles of the neogene frog Palaeobatrachus. Paleobiology 32: 666675.

Rot-Nikcevic I, Wassersug RJ. 2004. Arrested development in Xenopus laevis tadpoles: how size constrains metamorphosis. Journal of Experimental Biology 207: 2133-2145.

Rudolf NR, Haug C, Haug JT. 2016. Functional morphology of giant mole crab larvae: a possible case of defensive enrollment. Zoological Letters 2: 17.

Rybakov AV, Høeg JT, Jensen PG, Kolbasov GA. 2003. The chemoreceptive lattice organs in cypris larvae develop from naupliar setae (Thecostraca: Cirripedia, Ascothoracida and Facetotecta). Zoologischer Anzeiger-Journal of Comparative Zoology 242: 1-20.

Schreiber AM, Das B, Huang H, Marsh-Armstrong N, Brown DD. 2001. Diverse developmental programs of Xenopus laevis metamorphosis are inhibited by a dominant negative thyroid hormone receptor. Proceedings of the National Academy of Sciences 98: 10739-10744.

Shi Y-B, Hayes WP. 1994. Thyroid hormone-dependent regulation of the intestinal fatty acid-binding protein gene during amphibian metamorphosis. Developmental Biology 161: 48-58.

Sims HW. 1964. Four giant scyllarid phyllosoma larvae from the Florida Straits with notes on smaller similar specimens. Crustaceana 7: 259-266.

Sims HW, Brown CLJ. 1968. A giant scyllarid phyllosoma larva taken north of Bermuda (Palinuridea). Crustaceana. Supplement 12: 80-82.

Spengel J. 1932. Planctosphaera pelagica. Scientific Results "Michael Sars" North Atlantic Deep-Sea Expedition 5: 1-27.

Stampar SN, Morandini AC, Branco LC, da Silveira FL, Migotto AE. 2015. Drifting in the oceans: Isarachnanthus nocturnus (Cnidaria, Ceriantharia, Arachnactidae), an anthozoan with an extended planktonic stage. Marine Biology 162: 2161-2169. 
Stiasny G. 1928. Eine neue Tornaria aus der Adria. Zoologische Mededelingen 11: 37-45.

Strathmann RR. 1993. Review of 'Larvae and evolution: toward a new zoology', by DI Williamson. Quarterly Review of Biology 68: 280-282.

Strathmann RR, Bonar D. 1976. Ciliary feeding of tornaria larvae of Ptychodera flava (Hemichordata: Enteropneusta). Marine Biology 34: 317-324.

Tabeta O. 1970. A giant leptocephalus from the sea off northern Peru. Japanese Journal of Ichthyology 17: 80-81.

Temereva E, Malakhov VV, Chernyshev AV. 2006. Giant actinotroch, a larva of Phoronida from the South China Sea: the giant larva phenomenon. Doklady Biological Sciences 410: 410-413.

Thompson J. 1830. On the Cirripedes or Barnacles; demonstrating their deceptive character; the extraordinary metamorphosis they undergo, and the class of animals to which they indisputably belong. Natural History of Nondescript or Imperfectly Known Animals 1: 69-82.

Torres AP, Palero F, Dos Santos A, Abelló P, Blanco E, Boné A, Guerao G. 2014. Larval stages of the deep-sea lobster Polycheles typhlops (Decapoda, Polychelida) identified by DNA analysis: morphology, systematic, distribution and ecology. Helgoland Marine Research 68: 379-387.

Truman JW, Riddiford LM. 2002. Endocrine insights into the evolution of metamorphosis in insects. Annual Review of Entomology 47: 467-500.

Tzetlin AB. 1998. Giant pelagic larvae of Phyllodocidae (Polychaeta, Annelida). Journal of Morphology 238: 93-107.

Van der Horst C. 1936. Planktosphaera and tornaria. Quarterly Journal of Microscopic Science 78: 605-613.

Veillet A. 1943. Existence d'un "flotteur" chez la larve nauplius de certains Rhizocéphales. Bulletin de l'Institut océanographique de Monaco 845: 1-4.

Walker G. 1974. The fine structure of the frontal filament complex of barnacle larvae (Crustacea: Cirripedia). Cell and Tissue Research 152: 449-465.
Walker G. 1992. Cirripedia. Pp. 249-311 in: Harrison F, Humes A, eds, Microscopic Anatomy of Invertebrates, Wiley, Amsterdam.

Walker G. 2001. Introduction to the Rhizocephala (Crustacea: Cirripedia). Journal of Morphology 249: 1-8.

Walossek D, Høeg JT, Shirley TC. 1996. Larval development of the rhizocephalan cirripede Briarosaccus tenellus (Maxillopoda: Thecostraca) reared in the laboratory: a scanning electron microscopy study. Hydrobiologia 328: 9-47.

Wear RB. 1968. Life-history studies on New Zealand Brachyura. New Zealand Journal of Marine and Freshwater Research 2: 698-707.

Werner EE. 1988. Size, scaling, and the evolution of complex life cycles. Pp- 60-81 in: Ebenman B, Persson L, eds, Size-Structured Populations: Ecology and Evolution, Springer, Berlin, Heidelberg.

Yorisue T, Kado R, Watanabe H, Høeg JT, Inoue K, Kojima S, Chan BKK. 2013. Influence of water temperature on the larval development of Neoverruca sp. and Ashinkailepas seepiophila - Implications for larval dispersal and settlement in the vent and seep environments. Deep Sea Research Part I: Oceanographic Research Papers 71: 33-39.

Young C. 1999. Marine invertebrate larvae. Pp. 89-97 in: Knobil E, Neill J, eds, Encyclopedia of Reproduction, Academic Press, San Diego.

Young C. 2002. A brief history and some fundamentals. Pp. 1-21 in: Young C, Sewell M, Rice M, eds, Atlas of marine invertebrate larvae, Academic Press, San Diego.

Yun-Bo S, Liezhen FU, Hsia SCV, Tomita A, Buchholz D. 2001. Thyroid hormone regulation of apoptotic tissue remodeling during anuran metamorphosis. Cell Research 11: 245-252.

Received: 28 November 2016

Revised and accepted: 15 May 2017

Published online: 23 October 2017

Editor: R. Vonk 